\title{
IODP Expedition 318: From Greenhouse to Icehouse at the Wilkes Land Antarctic Margin
}

\author{
by Carlota Escutia, Henk Brinkhuis, Adam Klaus, and \\ the IODP Expedition 318 Scientists
}

\begin{abstract}
Integrated Ocean Drilling Program (IODP) Expedition 318, Wilkes Land Glacial History, drilled a transect of sites across the Wilkes Land margin of Antarctica to provide a long-term record of the sedimentary archives of Cenozoic Antarctic glaciation and its intimate relationships with global climatic and oceanographic change. The Wilkes Land drilling program was undertaken to constrain the age, nature, and paleoenvironment of the previously only seismically inferred glacial sequences. The expedition (January-March 2010) recovered $\sim 2000$ meters of high-quality middle Eocene-Holocene sediments from water depths between 400 $\mathrm{m}$ and $4000 \mathrm{~m}$ at four sites on the Wilkes Land rise (U1355,
\end{abstract}

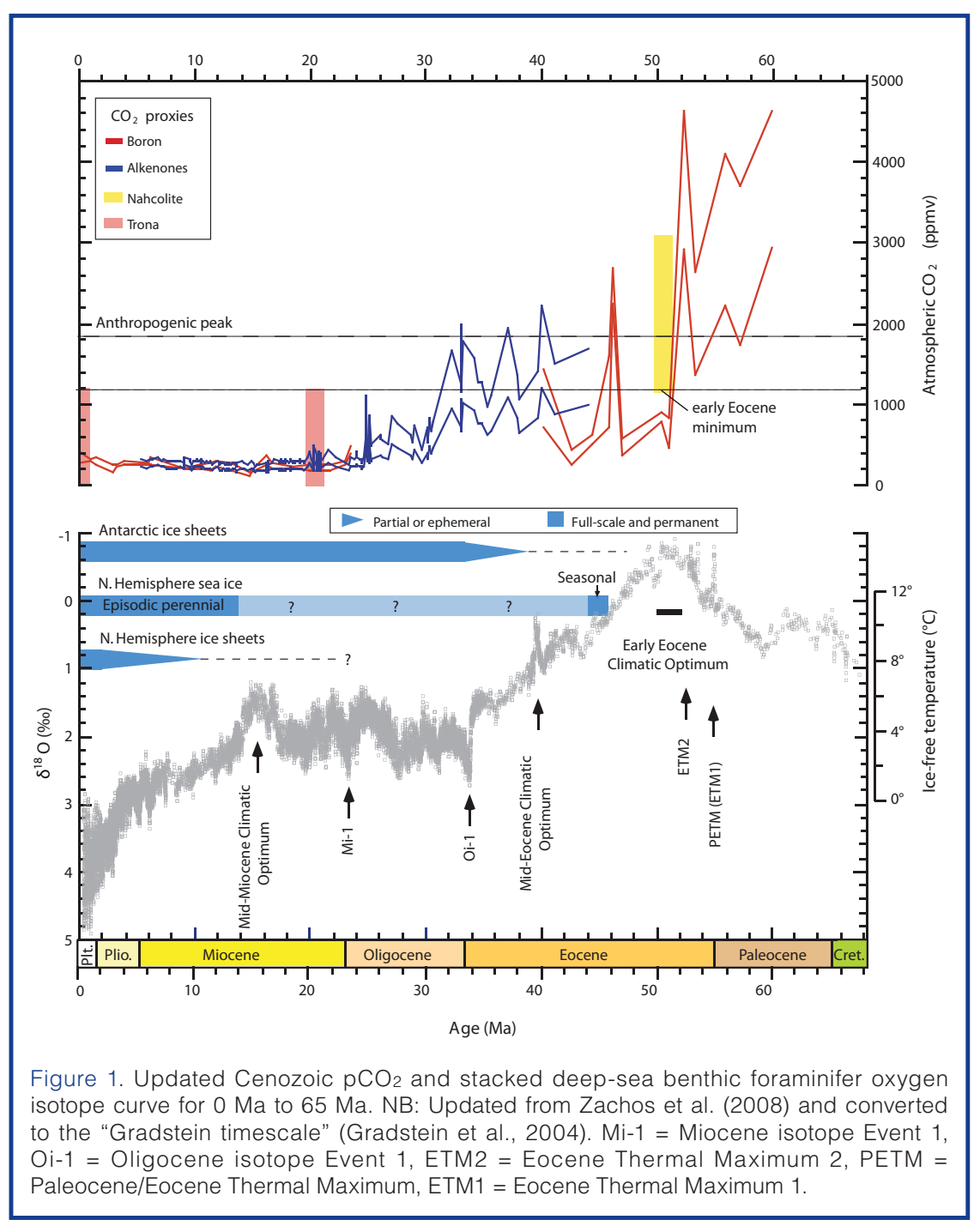

U1356, U1359, and U1361) and three sites on the Wilkes Land shelf (U1357, U1358, and U1360).

These records span $\sim 53$ million years of Antarctic history, and the various seismic units (WL-S4-WL-S9) have been successfully dated. The cores reveal the history of the Wilkes Land Antarctic margin from an ice-free "greenhouse" Antarctica, to the first cooling, to the onset and erosional consequences of the first glaciation and the subsequent dynamics of the waxing and waning ice sheets, all the way to thick, unprecedented "tree ring style" records with seasonal resolution of the last deglaciation that began $\sim 10,000$ y ago. The cores also reveal details of the tectonic history of the Australo-Antarctic Gulf from $53 \mathrm{Ma}$, portraying the onset of the second phase of rifting between Australia and Antarctica, to ever-subsiding margins and deepening, to the present continental and ever-widening ocean/continent configuration.

\section{Introduction}

Polar ice is an important component of the modern climate system, affecting among other things global sea level, ocean circulation and heat transport, marine productivity, air-sea gas exchange, and planetary albedo. The modern ice caps are, geologically speaking, a relatively young phenomenon. Since mid-Permian times $(\sim 270 \mathrm{Ma})$, parts of Antarctica became reglaciated only $\sim 34$ m.y. ago, whereas fullscale, permanent Northern Hemisphere continental ice began only $\sim 3$ m.y. ago (Zachos et al., 2008; Fig. 1). The record of Antarctic glaciation, from the time of first ice-sheet inception through the significant periods of climate change during the Cenozoic, is not only of scientific interest but also is of great importance for society. State-of-the-art climate models (DeConto and Pollard, 2003a, 2003b; Huber et al., 2004; DeConto et al., 2007; Pollard and DeConto, 2009) combined with paleoclimatic proxy data (Pagani et al., 2005) suggest that the main triggering mechanism for inception and development of the 


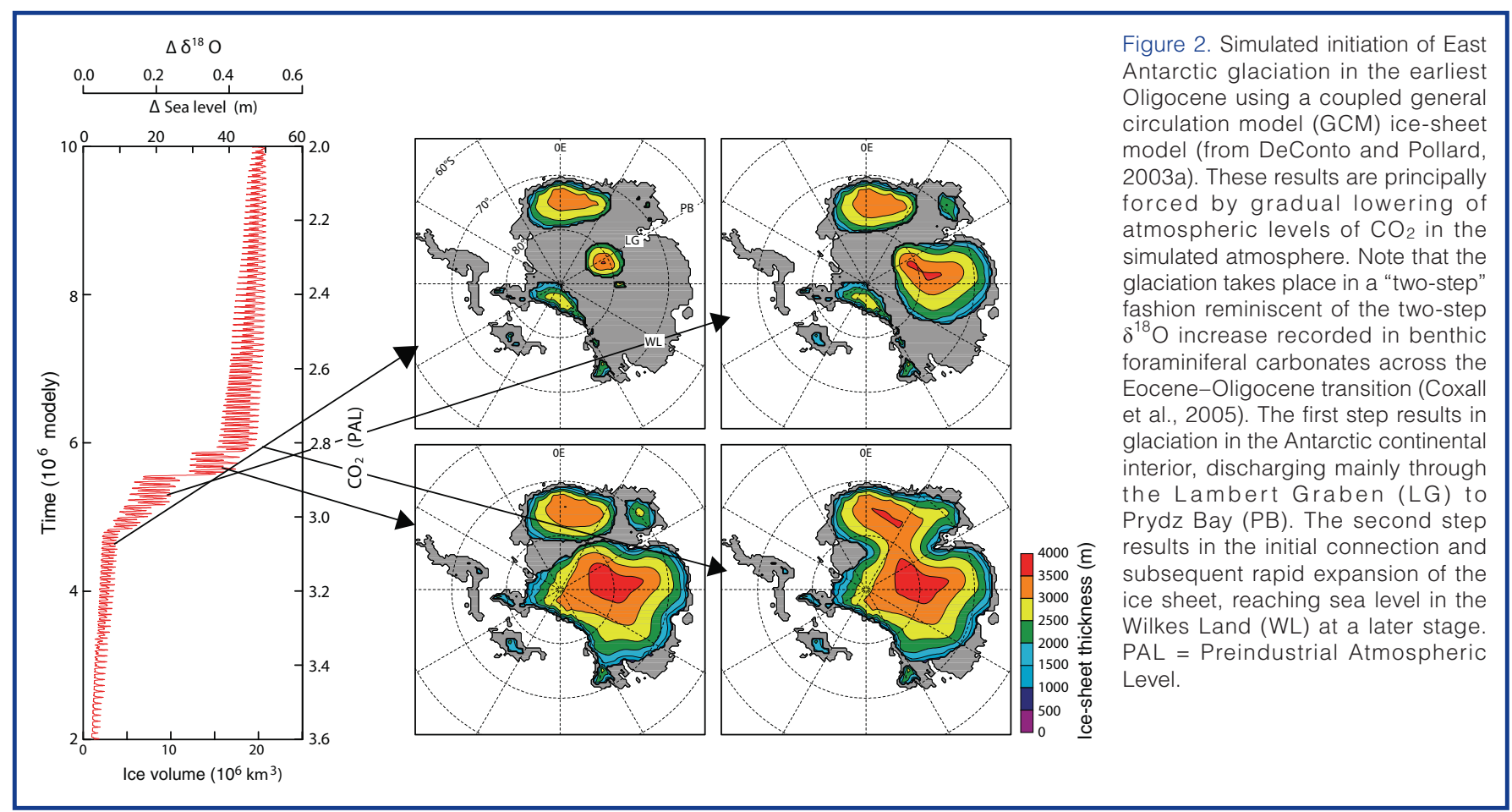

Antarctic ice sheet was the decreasing levels of $\mathrm{CO}_{2}$ (and other greenhouse gases) concentrations in the atmosphere (DeConto and Pollard, 2003a, 2003b; Figs 1, 2). The opening of critical Southern Ocean gateways played only a secondary role (Kennett, 1977; DeConto and Pollard, 2003a; Huber et al., 2004). With current rising atmospheric greenhouse gases resulting in rapidly increasing global temperatures (Intergovernmental Panel on Climate Change [IPCC], 2007; www.ipcc.ch/), studies of polar climates are prominent on the research agenda. Understanding Antarctic ice-sheet dynamics and stability is of special relevance because, based on IPCC (2007) forecasts, atmospheric $\mathrm{CO}_{2}$ doubling and a $1.8^{\circ} \mathrm{C}-4.2^{\circ} \mathrm{C}$ temperature rise is expected by the end of this century. The lower values of these estimates have not been experienced on our planet since 10-15 Ma, and the higher estimates have not been experienced since before the ice sheets in Antarctica formed.

Since their inception, the Antarctic ice sheets appear to have been very dynamic, waxing and waning in response to global climate change over intermediate and even short (orbital) timescales (Wise et al., 1991; Zachos et al., 1997; Pollard and DeConto, 2009). However, not much is known about the nature, cause, timing, and rate of processes involved. Of the two main ice sheets, the West Antarctic Ice Sheet (WAIS) is mainly marine based and is considered less stable (Florindo and Siegert, 2009). The East Antarctic Ice Sheet (EAIS), which overlies continental terrains that are largely above sea level, is considered stable and is believed to respond only slowly to changes in climate (Florindo and
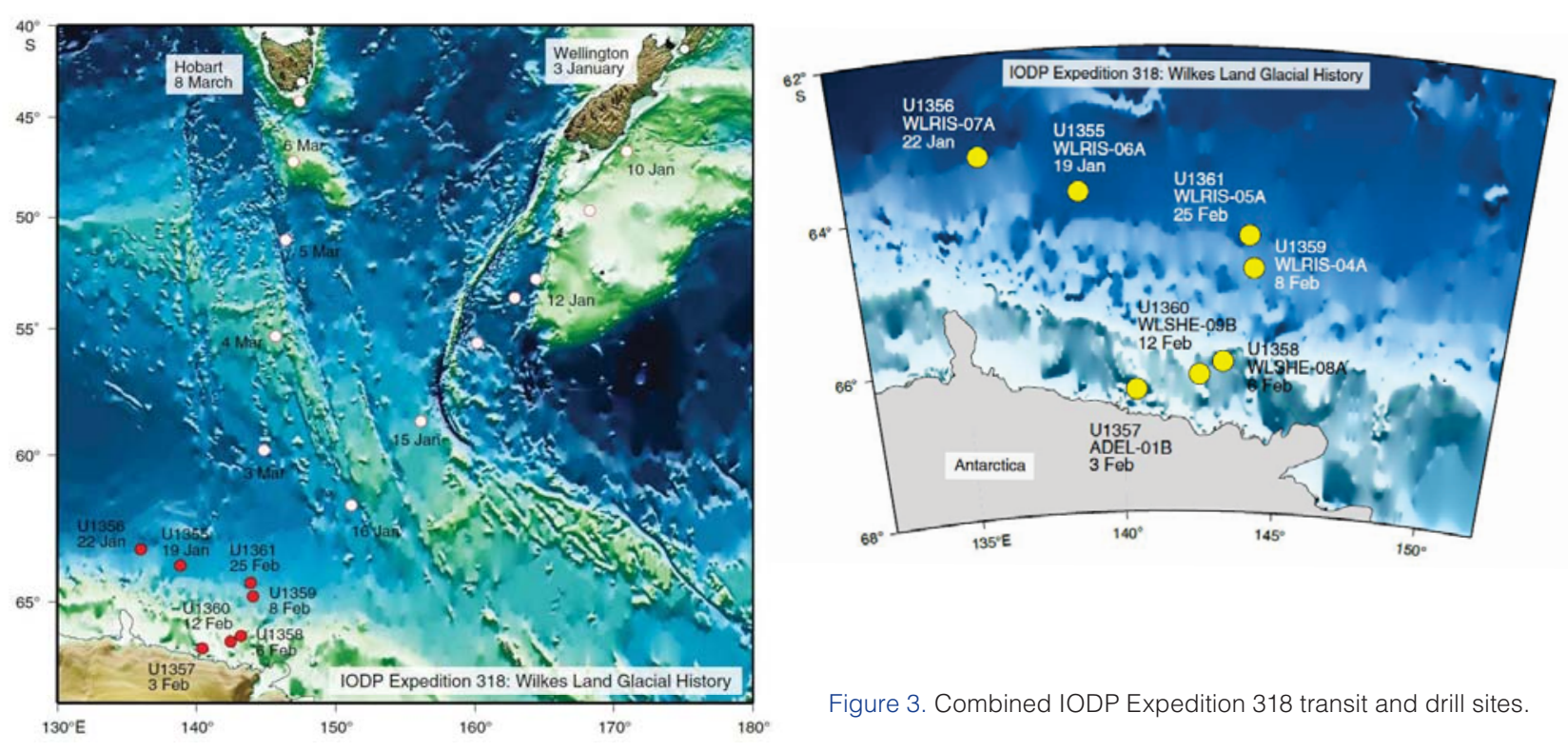

Figure 3. Combined IODP Expedition 318 transit and drill sites. 


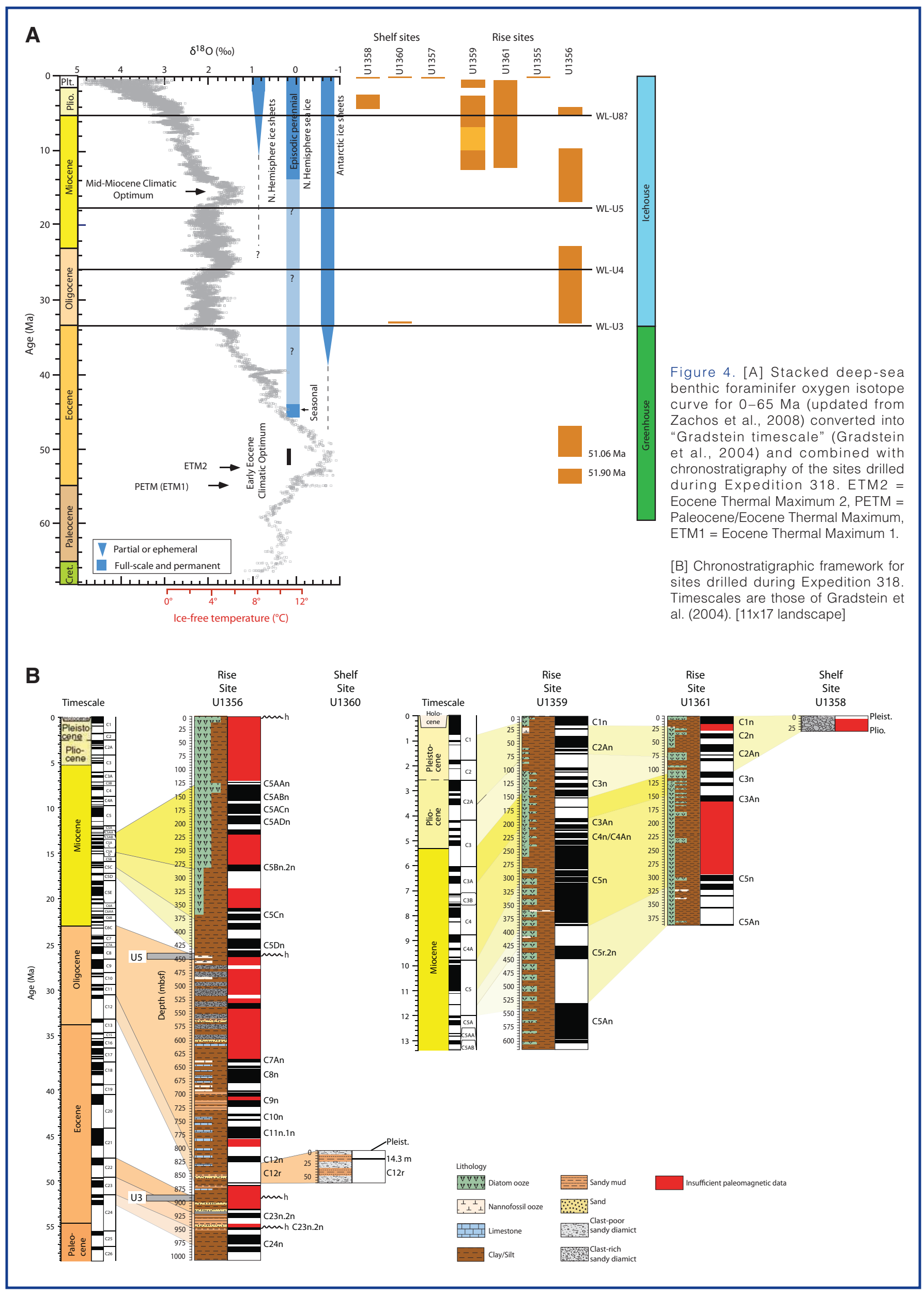


Siegert, 2009). However, reports of beach gravel deposited $20 \mathrm{~m}$ above sea level in Bermuda and the Bahamas from $420 \mathrm{ka}$ to $360 \mathrm{ka}$ indicate the collapse of not only the WAIS (6 $\mathrm{m}$ of sea-level equivalent, SLE) and Greenland ice sheet (6 m of SLE), but possibly also $8 \mathrm{~m}$ of SLE from East Antarctic ice sources (Hearty et al., 1999). Therefore, during episodes of global warmth, with likely elevated atmospheric $\mathrm{CO}_{2}$ conditions, the EAIS may contribute just as much or more to rising global sea level as the Greenland ice sheet. In the face of rising $\mathrm{CO}_{2}$ levels (Pachauri, R.K., and Reisinger, A., 2007), a better understanding of the EAIS dynamics is therefore urgently needed from both an academic as well as a societal point of view.

A key region for analysis of the long- and short-term behavior of the EAIS is the eastern sector of the Wilkes Land margin, located at the seaward termination of the largest East Antarctic subglacial basin, the Wilkes subglacial basin. The base of the portion of the EAIS draining through the Wilkes subglacial basin is largely below sea level, suggesting that this portion of the EAIS can potentially be less stable than other areas of the EAIS (Escutia et al., 2005). Numerical models of ice-sheet behavior (Huybrechts, 1993; DeConto and Pollard, 2003a, 2003b; DeConto et al., 2007; Pollard and DeConto, 2009) provide a basic understanding of the climatic sensitivity of particular Antarctic regions for early ice-sheet formation, connection and expansion, and eventual development of the entire ice sheet. For example, in these models glaciation is shown to have begun in the East Antarctic interior, discharging mainly through the Lambert Graben to Prydz Bay. These models imply that the EAIS did not reach the Wilkes Land margin until a later stage. These models can only be validated through drilling and obtaining direct evidence from the sedimentary record.

\section{Scientific Objectives}

The overall objectives of Expedition 318 were to date the identified seismic units and to obtain long-term records of Antarctic glaciation to better understand its relationships with global paleoclimate and paleoceanographic changes. Of particular interest is testing the sensitivity of the EAIS to episodes of global warming and detailed analysis of critical periods in Earth's climate history, such as the Eocene-Oligocene and Oligocene-Miocene glaciations, late Miocene, Pliocene, and the last deglaciation. During these times, the Antarctic cryosphere evolved in a step-wise fashion to ultimately assume its present-day configuration, characterized by a relatively stable EAIS. Conceivably even more important than the history of the Antarctic glaciations are past lessons of deglaciations and periods of exceptional warmth. We therefore planned to core several sequences from the Pleistocene and Pliocene that formed during interglacial intervals of exceptional warmth, periods that may provide valuable information about Antarctica's response to warming predicted in the centuries ahead. Furthermore, seismic reflection and shallow coring data indicate that the

Wilkes Land margin also includes sites with ultrahigh accumulation rates of sediments that document the Holocene deglaciation and subsequent climate and sedimentological variability extending over the past $10,000 \mathrm{y}$. In general, our strategy was to core and analyze sedimentary records along the inshore-offshore transect to constrain the age, nature, and environments of deposition, until now only inferred from seismic surveys of the Wilkes Land continental shelf, rise, and abyssal plain (Escutia et al., 1997; De Santis et al., 2003; Escutia et al., 2005).

\section{The Expedition}

IODP Expedition 318 (January-March 2010; Wellington, New Zealand, to Hobart, Australia), occupied seven sites (Fig. 3) across the Wilkes Land Margin at water depths between $\sim 400 \mathrm{mbsl}$ and $4000 \mathrm{mbsl}$. Together, we retrieved $\sim 2000$ meters of high-quality upper Eocene-Quaternary sedimentary cores (Fig. 4a, b). Sites U1355, U1356, U1359, and U1361 are on the Wilkes Land rise, and Sites U1358, U1360, and U1357 are on the Wilkes Land shelf. The cores span $~ 53$ m.y. of Antarctic history, revealing the history of the Wilkes Land Antarctic margin from an ice-free "greenhouse Antarctica," to the first cooling, to the onset and erosional consequences of the first glaciation and the subsequent dynamics of the waxing and waning ice sheets (Fig. 4). Furthermore, we also were able to capture the record of the last deglaciation in terms of thick, unprecedented "tree ring style" records with annual to seasonal resolution taken in the Adélie depression (U1357) (Fig. 5).

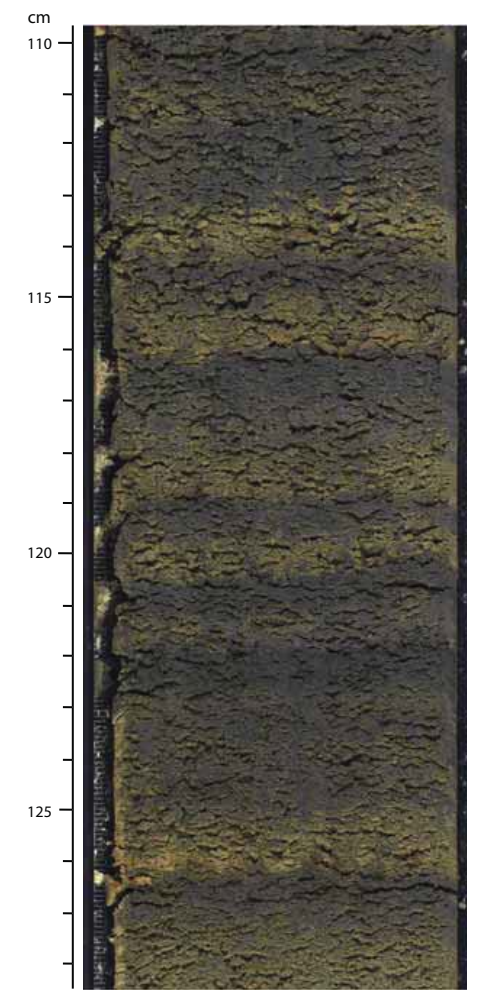

Figure 5.Example of a core section from Holocene diatomaceous ooze. Site U1357. Note the distinct seasonal laminations.
Initial studies now also reveal details of the tectonic history of the Australo-Antarctic Gulf (at $53 \mathrm{Ma}$ ), the onset of the second phase of rifting between Australia and Antarctica (Colwell et al., 2006; Close et al., 2009), ever-subsiding margins and deepening, to the present ocean/continent configuration. Tectonic and climatic change turned the initially shallow, broad subtropical Antarctic Wilkes Land offshore shelf into a deeply subsided basin with a narrow ice-infested margin (Fig. 6). 


\section{“Pre-Glacial” Regional Unconformity WL-U3 and the Timing, Nature, and Consequences of the First Major Phase of EAIS Growth}

Prior to the expedition, the prominent unconformity WL-U3 had been interpreted to separate pre-glacial (Eocene) strata from (Oligocene) glacial-influenced deposits (Escutia et al., 1997, 2005). Drilling and dating of WL-U3 at continental rise Site U1356 and shelf Site U1360 (Fig. 3) confirmed that this surface represents major erosion related to the onset of glaciation at $\sim 34 \mathrm{Ma}$ (early Oligocene), with immediately overlying deposits dated as 33.6 Ma (Fig. 7). Below unconformity WL-U3 at Site U1356, we recovered a record that is late early to early middle Eocene in age and that includes peak greenhouse conditions and likely some of the early Eocene hyperthermals (Fig. 8). We infer subtropical shallow-water depositional environments for this section based on dinocysts, pollen and spores, and the chemical index of alteration, among other indicators. A hiatus spanning $\sim 2$ m.y. separates the lower Eocene from the middle Eocene record at Site U1356 according to dinocyst and magnetostratigraphic evidence. This hiatus may be related to tectonic activity related to the commencement of rapid seafloor spreading in the Australia-Antarctic Basin (AAB), reported to initiate around the same time ( $50 \mathrm{Ma}$; Colwell et al., 2006). Also, combined Site U1356 and ODP Leg 189 dinocyst distribution patterns suggest earliest through-flow of South Pacific Antarctic waters through the Tasmanian Gateway to be coeval with this tectonic phase. Sedimentological and microfossil information from this interval from Hole U1356A also suggest some deepening during the early middle Eocene.

At Site U1356, the upper middle Eocene to the basal Oligocene is conspicuously missing in a 19 -m.y. hiatus at $\sim 890$ bsf ( 47.9-33.6 Ma) marking unconformity WL-U3 based on dinocyst and paleomagnetic evidence. Despite ongoing tectonic reorganizations, it appears likely that the erosive nature of unconformity WL-U3 is notably related to the early stages of EAIS formation. The impact of ice-sheet growth, including crustal and sea-level response, and major erosion by the ice sheets, is proposed as the principal mechanism that formed unconformity WL-U3. This is supported by the abrupt increase in benthic foraminiferal $\delta^{18} \mathrm{O}$ values and

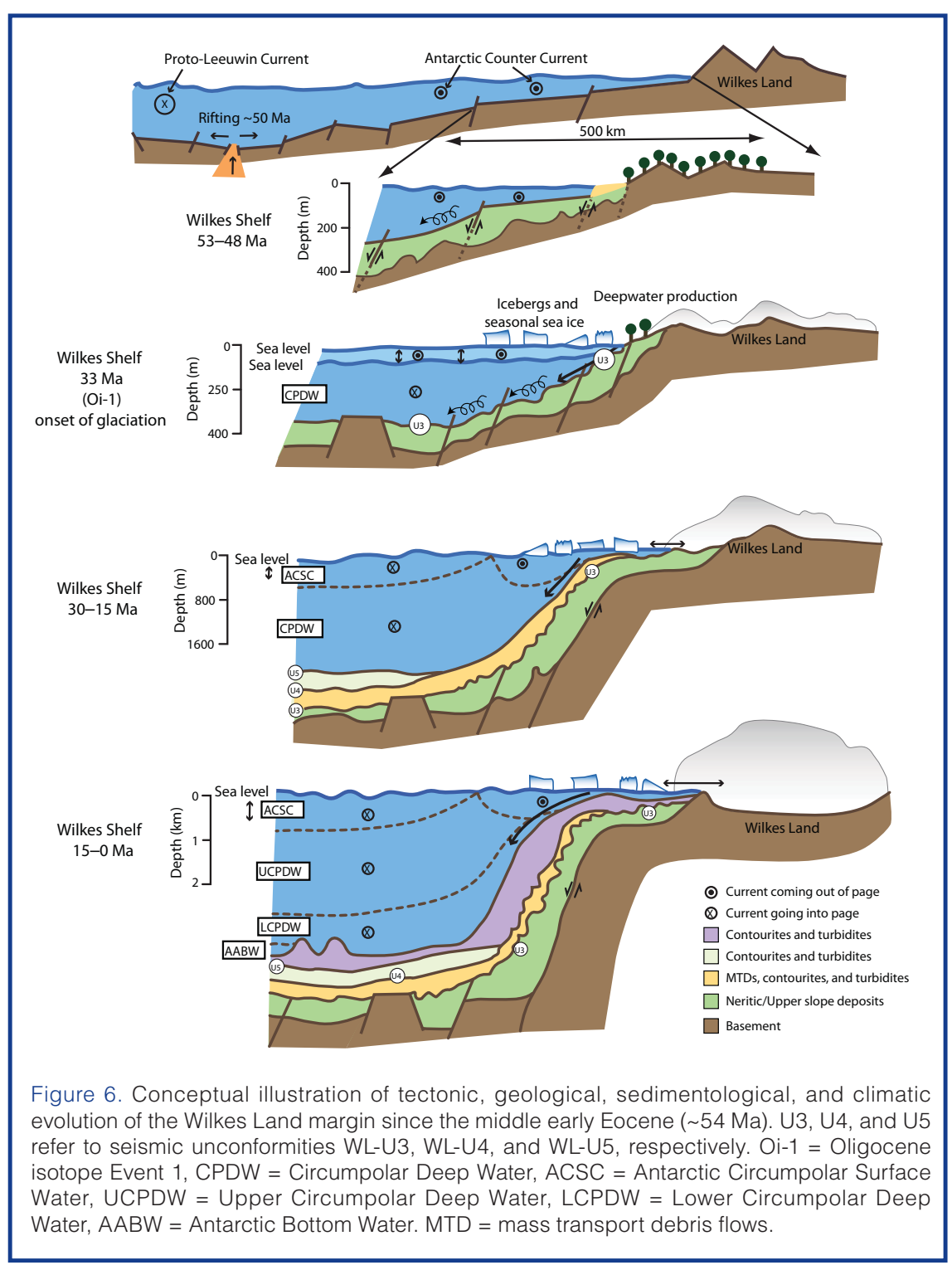

coeval sea-level change globally recorded in complete marine successions (Oligocene isotope event Oi-1; Miller et al., 1985; Coxall et al., 2005). Progressive subsidence-the large accommodation space created by erosion in the margin (300-600 $\mathrm{m}$ of missing strata; Eittreim et al., 1995) — and partial eustatic recovery allowed sediments of early Oligocene age to accumulate above unconformity WL-U3.

Microfossils, sedimentology, and geochemistry of the Oligocene sediments from Site U1356, at present occupying a distal setting (i.e., lowermost rise-abyssal plain) and immediately above unconformity WL-U3, unequivocally reflect icehouse environments with evidence of iceberg activity (dropstones) and at least seasonal sea-ice cover. The sediments, dominated by hemipelagic sedimentation with bottom current and gravity flow influence, as well as biota, indicate deeper water settings relative to the underlying middle Eocene environments. These findings imply significant crustal stretching, subsidence of the margin, and deepening of the Tasman Rise and the Adélie Rift Block (ARB) between 47.9 $\mathrm{Ma}$ and $33.6 \mathrm{Ma}$ (Fig. 6).

\section{Record of EAIS Variability}

Drilling at continental rise Site U1356 also recovered a thick section of Oligocene 
to upper Miocene sediments (Figs. 4, 8) indicative of a relatively deep-water, sea-ice-influenced setting. Oligocene to upper Miocene sediments are indicative of episodically reduced oxygen conditions either at the seafloor or within the upper sediments prior to $17 \mathrm{Ma}$. From the late early Miocene ( $\sim 17 \mathrm{Ma})$ onward, progressive deepening and possible intensification of deep-water flow and circulation led to a transition from a poorly oxygenated low-silica system (present from the early to early middle Eocene to late early Miocene) to a well-ventilated silica-enriched system akin to the modern Southern Ocean. This change coincides with one of the major regional unconformities in the Wilkes Land margin, unconformity WL-U5, which represents a $\sim 3$ m.y. latest Oligocene-early Miocene hiatus (Figs. 4, 8). This unconformity marks a change in the dominant sedimentary processes at this site, which are dominated by mass transport processes below the unconformity and by hemipelagic, turbidity flow, and bottom-current deposition above.

A complete record with good recovery of late Miocene to Pleistocene deposits was achieved at continental rise Sites U1359 and U1361 (Figs. 4, 9), drilled on levee deposits bounding turbidity channels. We successfully dated the seismic units between unconformities WL-U6 and WL-U8, and the sedimentological, wireline logging, and magnetic susceptibility data exhibit relatively high amplitude variations, indicating strong potential for this record to reveal EAIS dynamics down to orbital timescales (100 k.y. and 40 k.y. cyclicity) (Fig. 10). This cyclicity likely documents the successive advances and retreats of the ice-sheet and sea-ice cover, as well as the varying intensity of cold saline density flows related to bottom water production at the Wilkes Land margin (e.g., high-salinity shelf water flowing from the shelf into the deep ocean to form Antarctic Bottom Water $[\mathrm{AABW}])$. In general, typical Southern
Ocean open cold-water taxa, with variable abundances of sea-ice-associated diatoms were recovered, indicating a high-nutrient, high-productivity sea-ice-influenced setting throughout the Neogene. Combined sedimentological and microfossil information indicates the ever-increasing influence of typical Antarctic Counter Current surface waters and intensifying AABW flow. Furthermore, the preservation of calcareous microfossils in several intervals indicates times when bottom waters were favorable to the preservation of calcium carbonate. These observations point to a very dynamic ice-sheet/sea-ice regime during the late Miocene through the Pleistocene. Detailed postcruise studies in sediments from the late Neogene will provide a history of glacial-interglacial climate and paleoceanographic variability, including a history of AABW production that can be linked to sea-ice variations in this margin.

\section{Ultrahigh Resolution Holocene Record of Climate Variability}

Coring at Site U1357 yielded a 186-m section of continuously laminated diatom ooze as well as a portion of the underlying Last Glacial Maximum diamict. Based on much shorter piston cores recovered from adjacent basins and banks, the onset of marine sedimentation during the deglacial interval began between 10,400 y and 11,000 y ago. The site was triple cored, providing overlapping sequences that will aid in the construction of a composite stratigraphy spanning at least the last 10,000 y. The Site U1357 sediments are unusual for Antarctic shelf deposits because of their high accumulation rate $\left(2 \mathrm{~cm} \mathrm{y}^{-1}\right)$, lack of bioturbation, and excellent preservation of organic matter as well as calcareous, opaline, phosphatic, and organic fossils. The sediments are profoundly anoxic, with levels of $\mathrm{H}_{2} \mathrm{~S}$ as high as $42,000 \mathrm{ppm}$ at 20 mbsf. Larger burrowing organisms are completely

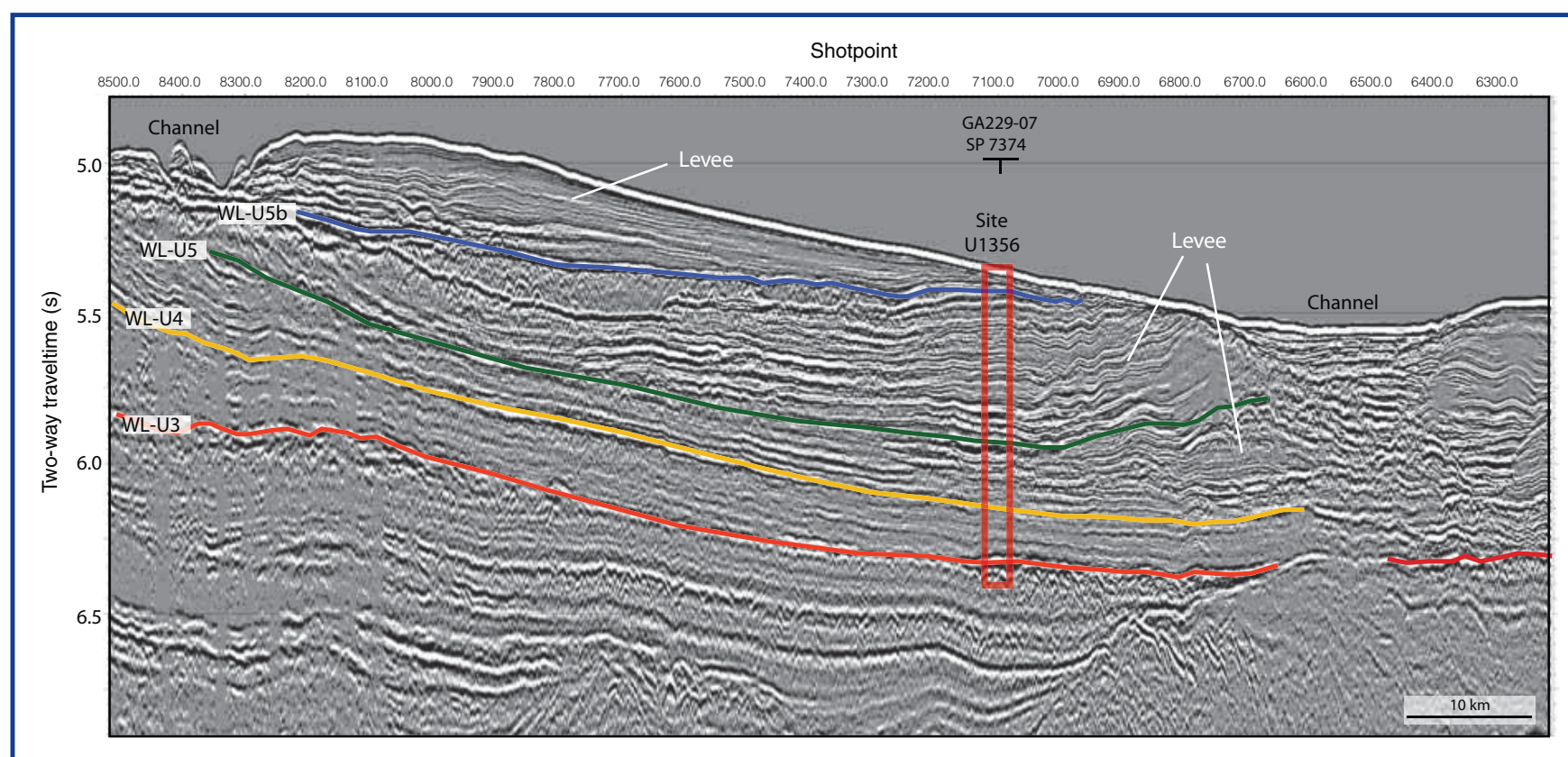

Figure 7. Multichannel seismic reflection profile across Site U1356 showing regional unconformities WL-U3, WL-U4, and WL-U5. Red rectangle = approximate penetration achieved at Site U1356. 

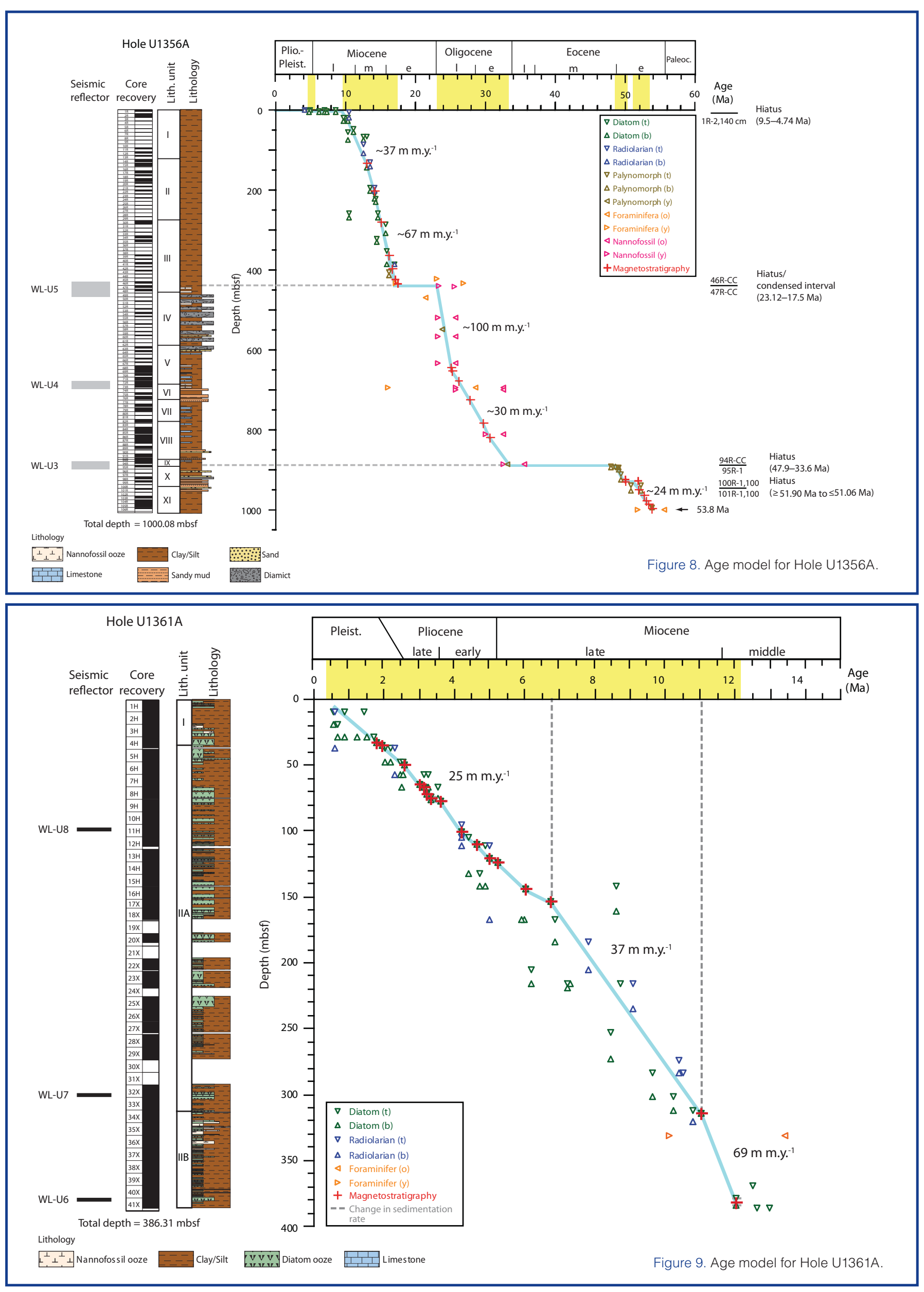
excluded from this ecosystem, yet the regular occurrence of benthic foraminifers suggests that some oxygen is present at the sediment-water interface. These sediments provide an excellent sample set for geomicrobiology and sedimentary geochemistry studies. In fact, the upper $20 \mathrm{~m}$ of one of the three holes was intensively sampled for integrated pore water and microbiological studies.

A paramount achievement from a paleoclimatic standpoint was the retrieval of this continuously laminated deposit (Fig. 5). Spot checks of laminae from top to bottom of the split Hole U1357A sections suggest that paired light-dark laminae sets range in thickness from $\sim 1 \mathrm{~cm}$ to $3 \mathrm{~cm}$. Based on radiocarbon dating of a piston core taken earlier from this site (Costa et al., 2007), our own preliminary secular paleomagnetic findings, and the thickness of the deposit combined with the expected age at its base, it is very likely each laminae pair represents one year. If supported by our shore-based research, this will be the first varved sedimentary sequence extending through the Holocene recovered from the Southern Ocean. Analysis at the annual timescale will permit us to examine decadal to subdecadal variability in sea ice, temperature, and wind linked to the Southern Annual Mode (SAM), Pacific Decadal Variability, and possibly ENSO. We will also be able to address questions regarding rates of change during the Hypsithermal Holocene neoglacial events and the time immediately following the first lift-off and pull-back of ice at the end of the last glacial interval. In addition, we now have an excellent opportunity for ultrahigh resolution correlation to the nearby Law Dome Ice Core, one of the most important Holocene ice cores in Antarctica.

\section{Acknowledgements}

We thank the captain and crew of the JOIDES Resolution, the IODP 318 operation superintendent, ice pilot, weatherman, all technicians, and videographer who were instrumental in the success of Expedition 318. They allowed and assisted us in drilling, documenting, sampling, and onboard sample analyses during Expedition 318. Numerous people at IODP-TAMU as well as USIO provided their dedicated effort supporting us, including preparation of the expedition and publication of the proceedings. The USIO curatorial team provided us with their able support during the sampling party at College Station. We also thank the co-PIs of the Proposal 482 and APL 638 and the master of the R/V Astrolabe for his support.

\section{The IODP Expedition 318 Scientists}

C. Escutia (Chief Scientist), H. Brinkhuis (Chief Scientist), A. Klaus (Staff Scientist), J.A.P. Bendle, P.K. Bijl, S.M. Bohaty, S.A. Carr, R.B. Dunbar, J.J. Gonzàlez, A. Fehr, T.G. Hayden, M. Iwai, F.J. Jimemez-Espejo, K. Katsuki, G.S. Kong, R.M. McKay, M. Nakai, M.P. Olney, S. Passchier, S.F. Pekar, J. Pross, C. Riesselman, U. Röhl, T. Sakai, P.K. Shrivastava, C.E. Stickley, S. Sugisaki, L. Tauxe, S. Tuo, T. van de Flierdt, K. Welsh, T. Williams, M. Yamane .

\section{References}

Close, D.I., Watts, A.B., and Stagg, H.M.J., 2009. A marine geophysical study of the Wilkes Land rifted continental margin, Antarctica. Geophys. J. Int., 177(2):430-450, doi:10.1111/j. 1365-246X.2008.04066.x.

Colwell, J.B., Stagg, H.M.J., Direen, N.G., Bernander, G., and Borisova, I., 2006. The structure of the continental margin off Wilkes Land and Terre Adelie Coast, East Antarctica. In Futterer, D.K., Damaske, D., Kleinschmidt, G., Miller, H., and Tessensohn, F. (Eds.), Antarctica: Contributions to Global Earth Sciences, Berlin (Springer-Verlag), 327-340. 
Costa, E., Dunbar, R.B., Kryc, K.A., Mucciarone, D.A., Brachfeld, S., Roark, E.B., Manley, P.L., Murray, R.W., and Leventer, A., 2007. Solar forcing and El Niño-Southern Oscillation (ENSO) influences on productivity cycles interpreted from a late Holocene high-resolution marine sediment record, Adélie Drift, East Antarctic margin. In Cooper, A.K., and Raymond, C.R., and the ISAES Editorial Team. (Eds.), Antarctica: A Keystone in a Changing World - Proceedings for the Tenth International Symposium on Antarctic Earth Sciences. USGS Open File Rep., 2007-1047. Washington, DC (The National Academies Press), 1-6, doi:10.3133/of20071047.srp036.

Coxall, H.K., Wilson, P.A., Pälike, H., Lear, C.H., and Backman, J., 2005. Rapid stepwise onset of Antarctic glaciation and deeper calcite compensation in the Pacific Ocean. Nature, 433(7021):53-57, doi:10.1038/nature03135.

DeConto, R.M., and Pollard, D., 2003a. A coupled climate-ice sheet modeling approach to the early Cenozoic history of the Antarctic ice sheet. Palaeogeogr., Palaeoclimatol., Palaeoecol., 198(1-2):39-52, doi:10.1016/S0031-0182(03) 00393-6.

DeConto, R.M., and Pollard, D., 2003b. Rapid Cenozoic glaciation of Antarctica induced by declining atmospheric $\mathrm{CO}_{2}$. Nature, 421(6920):245-249, doi:10.1038/nature01290.

DeConto, R., Pollard, D., and Harwood, D., 2007. Sea ice feedback and Cenozoic evolution of Antarctic climate and ice sheets. Palaeoceanography, 22(3):PA3214, doi:10.1029/2006PA 001350.

De Santis, L., Brancolini, G., and Donda, F., 2003. Seismostratigraphic analysis of the Wilkes Land Continental Margin (East Antarctica): influence of glacially driven processes on the Cenozoic deposition. Deep Sea Res. Part II, 50(8-9):1563-1594, doi:10.1016/S0967-0645(03)00079-1.

Eittreim, S.L., Cooper, A.K., and Wannesson, J., 1995. Seismic stratigraphic evidence of ice-sheet advances on the Wilkes Land margin of Antarctica. Sediment. Geol., 96(1-2):131-156, doi:10.1016/0037-0738(94)00130-M.

Escutia, C., De Santis, L., Donda, F., Dunbar, R.B., Cooper, A.K., Brancolini, G., and Eittreim, S.L., 2005. Cenozoic ice sheet history from East Antarctic Wilkes Land continental margin sediments. Global Planet. Change, 45(1-3):51-81, doi:10.1016/j.gloplacha.2004.09.010.

Escutia, C., Eittreim, S.L., and Cooper, A.K., 1997. Cenozoic sedimentation on the Wilkes Land continental rise, Antarctica. In Ricci, C.A. (Ed.), The Antarctic Region: Geological Evolution and Processes. Proc. Int. Symp. Antarct. Earth Sci., 7:791-795.

Florindo, F., and Siegert, M., 2009. Antarctic Climate Evolution. Developments in Earth and Environmental Sciences, Vol. 8: Amsterdam, The Netherlands (Elsevier).

Gradstein, F.M., Ogg, J.G., and Smith, A., 2004. A Geologic Time Scale 2004: Cambridge (Cambridge University Press).

Hearty, P.J., Kindler, P., Cheng, H., and Edwards, R.L., 1999. A +20 m middle Pleistocene sea-level highstand (Bermuda and the Bahamas) due to partial collapse of Antarctic ice. Geology, 27(4):375-378, doi:10.1130/0091-7613(1999) 027 $<0375$ :MMPSL $>2.3 . C O ; 2$.

Huber, M., Brinkhuis, H., Stickley, C.E., Döös, K., Sluijs, A., Warnaar, J., Schellenberg, S.A., and Williams, G.L., 2004. Eocene circulation of the Southern Ocean: was Antarctica kept warm by subtropical waters? Paleoceanography, 19(4):PA4026, doi:10.1029/2004PA001014.

Huybrechts, P., 1993. Glaciological modelling of the Late Cenozoic East Antarctic Ice Sheet: stability or dynamism? Geograf. Ann., 75(4):221-238m, doi:10.2307/521202.

Intergovernmental Panel on Climate Change (IPCC), The AR4 Synthesis Report 2007: http://www.ipcc.ch/

Kennett, J.P., 1977. Cenozoic evolution of Antarctic glaciation, the circum-Antarctic Ocean, and their impact on global paleoceanography. J. Geophys. Res., 82(27):3843-3860, doi:10.1029/JC082i027p03843.

Miller, K.G., Aubry, M.-P., Kahn, M.J., Melillo, A.J., Kent, D.V., and Berggren, W.A., 1985. Oligocene-Miocene biostratigraphy, magnetostratigraphy, and isotopic stratigraphy of the western North Atlantic. Geology, 13(4):257-261, doi:10.1130/009 17613(1985) $13<257$ :OBMAIS $>2.0 . C O ; 2$.

Pagani, M., Zachos, J.C., Freeman, K.H., Tipple, B., and Bohaty, S., 2005. Marked decline in atmospheric carbon dioxide concentrations during the Paleogene. Science, 309(5734):600603, doi:10.1126/science.1110063.

Pollard, D., and DeConto, R.M., 2009. Modelling West Antarctic ice sheet growth and collapse through the past five million years. Nature, 458(7236):329-332, doi:10.1038/ nature07809.

Wise, S.W., Jr., Breza, J.R., Harwood, D.M., and Wei, W., 1991. Paleogene glacial history of Antarctica. In Müller, D.W., McKenzie, J.A., and Weissert, H. (Eds.), Controversies in Modern Geology: Evolution of Geological Theories in Sedimentology, Earth History and Tectonics: Cambridge (Cambridge University Press), 133-171.

Zachos, J.C., Dickens, G.R., and Zeebe, R.E., 2008. An early Cenozoic perspective on greenhouse warming and carbon-cycle dynamics. Nature, 451(7176):279-283, doi:10.1038/ nature 06588 .

Zachos, J.C., Flower, B.P., and Paul, H., 1997. Orbitally paced climate oscillations across the Oligocene/Miocene boundary. Nature, 388(6642):567-570, doi:10.1038/41528.

\section{Authors}

Carlota Escutia, Instituto Andaluz de Ciencias de la Tierra, CSIC-Universidad de Granada, Campus de Fuentenueva s/n, 18002 Granada, Spain, e-mail: cescutia@ugr.es.

Henk Brinkhuis, Biomarine Sciences, Institute of Environmental Biology, Laboratory of Palaeobotany and Palynology, Utrecht University, Budapestlaan 4, 3584 CD Utrecht, The Netherlands, e-mail: h.brinkhuis@uu.nl.

Adam Klaus, Staff Scientist/Expedition Project Manager, United States Implementing Organization, Integrated Ocean Drilling Program, Texas A\&M University, 1000 Discovery Drive, College Station, TX 77845-9547, U.S.A., e-mail: aklaus@iodp.tamu.edu.

\section{and the IODP Expedition 318 Scientists}

\section{Related Web Link}

http://publications.iodp.org/preliminary_report/318/ http://www.stratigraphy.org/ 